\title{
JAKE VE DINOS CHAPMAN'IN ESERLERINDE YENIDEN ÜRETIM VE FRANCISCO GOYA İLiŞKISi
}

\author{
CONNECTION BETWEEN REPRODUCTION AND FRANCISCO GOYA IN THE WORKS OF JAKE AND \\ DINOS CHAPMAN
}

Serkan Çalışkan *

\section{Öz}

Bu çalışma, Jake ve Dinos Chapman ikilisinin sanatta yeniden üretim bağlamında Francisco Goya'nın eserleri üzerinden ürettikleri eserlere odaklanmaktadır. Bu bağlamda, metnin içinde öncelikli olarak sanat nesnesi ve yeniden üretim ilişkisi araştırımaktadır. Bir şeyi değiştirmek, dönüştürmek ve onu başka bir şey yapmak, öncelikli olarak bellek kaybı gibi algılansa da, yeniden yapma, üretme belleği yeniden gündeme getirmektedir. Yeniden içinde taşıdığı bellekle bugüne gelen o nesne, anlamın bağlamını da değiştirir. Anlam tek olmaktan çıkar, öncelikli olarak ikincil bir anlam taşır ve bu devam eden sayısız anlamların oluşmasına neden olur. Bu nedenle, yeniden üretim bağlamında sanat eseri, çoklu sese sahiptir. Söylediği şey ise bir mesafe yaratmaktadır ki bu anlamda yapıtın çağdaşlığı tartışmaya açılmaktadır metin içinde. Chapmanların Goya'nın "Savaşın Felaketleri" adlı gravür serisinden yola çıkarak, çeşitlemelerle yeniden üretime geçtiği görülmektedir. İkili yapıtı bağlamından koparırken, modern sanat ve Aydınlanma felsefesinin altındaki sorunsalları da tartışmaktadır. Goya'nın eserleri yer değiştirirken, zamansal bir farkla tekrar görünürlük kazanmaktadır. Bununla birlikte Chapmanların tekrar tartışmaya açtıkları sanat nesnesi, Goya'dan bağımsız yapıtla yapıtın zamanı arasında bir mesafe kazanmaktadır.

Anahtar Kelimeler: Yeniden Üretim, Chapmanlar, Francisco Goya, Çağdaş Sanat.

\section{Abstract}

This study focuses on the works produced by Jake and Dinos Chapman through the works of Francisco Goya within the context of reproduction in art. In this context, the relationship between the object of art and reproduction was first investigated in the text. Although changing and transforming something and making it something else are basically perceived as the loss of memory, remaking and production make memory a current issue again. That object that has come to these days again with the memory it has also changes the context of meaning. Meaning ceases to be single, and it primarily has a secondary meaning which leads to ongoing formation of numerous meanings. Therefore, the work of art has a multiple phoneme within the context of reproduction. What it says creates a distance, in this sense, the contemporaneity of the work is brought up for discussion. It is seen that the Chapman started production with variations based on Goya's gravure series "Disasters of War". They also discuss the problems under modern art and Enlightenment philosophy while tearing the work from its context. Thus, while the works of Goya are replaced, they become visible again with a temporal difference. However, the object of art that the Chapman brought up for discussion again gains a distance between the work independent of Goya and the time of the work.

Keywords: Reproduction, Chapmans, Francisco Goya, Contemporary Art.

Araştırama Makalesi // Başvuru tarihi: 25.04.2019 - Kabul tarihi: 14.06.2019.

* Dr. Öğr. Üyesi, Kırklareli Üniversitesi, Lüleburgaz MYO, s.serkan.caliskan@gmail.com, https://orcid.org/0000 000213094574. 


\section{Sanat Tarihinde Yeniden Üretim}

Nicolas Bourriaud Postprodüksiyon adlı eserinde, 1960'lar sonrasında, modadan, sinemaya, müziğe ve plastik sanatlara ait üretim yapan birçok tasarımcı ve sanatçının yeniden üretime yöneldiğini örneklerle açıklamaktadır. Bu açıdan bakıldığında da, yeniden üretim ya da temellük kavramlarının postmodernizm ile yakın ilişkide olduğunu göstermektedir. Bu temas birincil anlamda esinlenmeden öteyi barındırmaktadır. Diğer bir deyişle, yeniden üretime alınan eser, esinlenmenin ötesindedir; bağlam ve anlam açısından bir önceki üretim nesnesi ile iletişim halindedir. Bourriaud bu durumu şu şekilde açıklamaktadır:

“...Tüm bu sanatsal pratikler, biçimsel olarak heterojen olmakla birlikte, hepsi de daha önce üretilmiş olan formları bir yardım aracı olarak kullanırlar. Sanat işini özerk ya da orijinal bir form olarak değerlendirmektense, onu göstergeler ve anlamlardan oluşan bir ağ içine yerleştirmeye ilişkin bir hevesi gözler önüne serer" (Bourriaud, 2014:28).

Bu açıklamalar ışığında yeniden üretimin bir tanımı yapıldığında, sanatta yeniden üretim, bir sanat nesnesinin yıllar sonra yeniden gündeme getirilerek, bazen dönüştürerek, eklentiler yaparak üretilmesi, bazen de tam aksi bulunduğu çağdan ve bağlamdan koparılıp günümüze getirilerek yeni bir bağlamın parçası olarak sergilenmesine denilmektedir.

Yukarıda da belirtildiği gibi, üretilen yeni sanat eseri, bir öncekinin aynısı olmak zorunda değildir. İlişki kurulan her iki eser arasındaki anlam benzerliği ve form, görsel benzerlik ne kadar benzeşse de, iki nesne arasında bir zamansal fark yaratmaktadır. Bu zaman kopukluğu, anlam ve bağlam açısından aradaki zamansal mesafenin yakınlaşmasına sebep olur. Diğer bir deyişle, aslında aradaki o uzun yıllar, çağlar ve yaşanan toplumsal farklılıkların birbirlerine çok da uzak olmadığını göstermektedir. Değişim olarak algılanan şeylere rağmen, farklı zamanlarda ve mekânlarda yaşayan alımlayıcılar, ortak benzerlikler taşıyabilmektedir.

Walter Benjamin "Tekniğin Olanlarıyla Yeniden Üretilebildiği Çağda Sanat Yapıtı" adlı eserinde, teknik olanaklarla sanat nesnesinin çoğaltılabilir olması ve aura kavramını tartışırken, sanat yapıtının biricikliğinin ikinci plana atılmasını tartışmıştır. Bu durum, yeniden üretimden ziyade çoğaltma, sinema ve fotoğraf üzerinden ilerletirken yeni kopyaların üretilmesinin, sanat nesnesinin bir nevi demokratikleşmesini akıllara getirmektedir. Oysa günümüzdeki teknik olanakların neredeyse sınırsızlığı içinde, başta video sanatı ve dijital sanatlar çoğaltılabilme 
konusunda çok fazla seçeneğe sahip ve yeniden üretime açık alanlara sahiptir. Ve bu alandaki sanat eserlerine bakıldığında da, yeniden üretim alanından oldukça fazla yararlanıldığı görülmektedir. Bununla birlikte Adorno'nun kitleleştirme kavramı yeniden üretim ile ilişkilenebilecek eleştirel bir tavır olarak algılanabilir. Yazara göre:

Kültür endüstrisi eski olanla tanıdık olanı yeni bir nitelikte birleştirir. Kitlelerin tüketimine göre düzenlenen ve büyük ölçüde tüketimin yapısını belirleyen ürünler, tüm sektörlerde az çok bir plana göre üretilir. Tüm sektörler yapısal olarak benzerdir ya da en azından birbirilerinin açıklarını kapatarak, neredeyse tamamen gediksiz bir sistem oluştururlar. Bunu olanaklı kılan sadece çağdaş teknik yeterlikler değil, aynı zamanda ekonomik ve yönetsel yoğunlaşmadır. Kültür endüstrisi kasıtlı olarak tüketicileri kendisine uydurur (Adorno, 2003:76).

Fakat yeniden üretimin sanatsal üretim açısından derdi, çoğaltılabilir olmaktan veya kitleleşmekten daha farklı anlamlar içerdiği söylenebilir. Bir önceki sanat eserini bağlamından koparıp, ona yeni bir anlam ve katman katmayı hedeflemektedir. Manipüle ettikleri materyal birincil değildir artık. Bundan böyle önemli olan ham materyali temel veri olarak alan bir formun ayrıntılarıyla ele alınması meselesi değil, kültürel pazarda çoktan dolaşımda olan nesnelerle, yeni diğer nesneler tarafından zaten daha önce aynı kalacak nesnelerle çalışma meselesidir. Orijinallik (bir şeyin kökeninde olma) ve hatta yaratım (hiçbir şeyden bir şey yapma) nosyonları, her ikisinin de işinin kültürel nesneleri seçme ve bunları yeni kavramlar içine sokma olan ayrılmaz ikili DJ ve programcının damgasını vurduğu bu yeni kültürel manzarada yavaş yavaş bulandırıyor (Bourriaud, 2004:22).

Bu durum alıntı-çalıntı, esinlenme-kopya tartışmalarını da beraberinde getirmiştir. Ali Artun 2013 yılında yayınlanan "Sahte Sanat" adlı makalesinde, Rönesans sanatında alıntı, çalıntı, kopya gibi ayrımların olmadığını söylerken, böyle bir ayrımın, yani orijinallik, özgünlük, sahih ve biriciklik kavramlarının 18. Yüzyılda ortaya çıktı̆̆ına değinmektedir (Artun, 2013:1). Bu açıklamalar bağlamında plastik sanatlara bakıldığında, postmodernizm öncesinde bazı örneklerin mevcut olduğu görülmektedir. Diğer yandan sanat tarihinde yeniden üretim kavramı günümüzde olduğu kadar yaygın olmasa da, bazı kült eserlerin yeniden üretimini görmek mümkündür. Örneğin Tiziano'nun Urbino Venüs'ü ve Manet'nin Olympia'sı bu yeniden üretim başlığı altında dikkat çekicidir. Yine Velazquez'in Las Meninas adlı eseri yıllar sonra Picasso tarafından yeniden üretilmiş, sanatçının kendi üslubuna dönüştürülmüş olarak karşımıza çıkmaktadır. 
Aynı zamanda edebiyatta da benzer bir şekilde, aynı konunun işlenişi görüşmektedir. 1659 yılında Corneille Antik Yunan dönemine ait en önemli tragedyalardan olan ve dönemin en önemli yazarlarından olan Sophokles'in "Oedipus"unu tekrar yazmaya başlar ve bazı değişiklikler yaparak oyunu Fransızca olarak yeniden yazar. "Corneille parçalara ayrılması imkansız olan kısımları ortadan kaldırmak adına, Sophokles'i tamamen nakletmekten vazgeçme ihtiyacı duyar ve Ödip suçluluğunu açığa çıkaran şemanın biçimini bütünüyle değiştirir" (Ranciere, 2006:17). Yazar Sophokles'in Oedipus eserine geri dönen ve esere müdahale edip dönüştüren Voltaire'den de bahsetmektedir. "...Genç Voltaire de yazarlık mesleğine başlangıç olarak kendine Oedipus konusunu seçer. Ancak Corneille'den daha açık yürekle Sophopkles'e öfkelendiği için yapar bunu, Kral Oedipus’un entrikasındaki “akıl-almaz şeyleri” ifşa eder” (Ranciere, 2006:17).

Yeniden üretim kavramı üzerine düşünülmeye ve tartışılmaya başlanması ve bu durumun plastik sanatları etkilemesi özellikle 1990'lı yıllardan sonra olmuş ve eserlere yansımaya başlamıştır. Çünkü daha önce de değinildiği gibi, çă̆ımızın teknik imkânları ile yeniden üretim arasında ciddi bir ilişki vardır. Postmodernizm düşünce ve anlatı anlamındaki katkıları ve teknolojinin devrimsel nitelikteki dönüşümü, görsel sanatlarda eklektik ya da var olanı bozup yeniden inşa etme üzerinden bir eğilime yönelmektedir.

Doksanlı yılların başından beri gittikçe artan sayıdaki sanat işleri daha önce var olan çalışmalardan yola çıkılarak yaratılıyor; giderek daha fazla sanatçı başkaları tarafından yapılmış çalışmaları ya da hali hazırdaki kültürel ürünleri yorumluyor, yeniden üretiyor, yeniden sergiliyor veya kullanıyor. Kullanıma hazır işlerin sayısındaki bu artış ve şimdiye değin görmezden gelinen ya da küçümsenen formaların sanat dünyasına katılması ile karakterize edilen bu postprodüksiyon sanat, bilgi çağında küresel kültürün hızla yayılan kaosuna bir tepki gibi gözüküyor. Kendi işlerini diğer insanların işlerine yerleştiren bu sanatçılar, üretim ve tüketim, yaratı ve kopya, hazır nesne ve orijinal iş arasındaki geleneksel ayrımın kökünün kazınmasında rol oynuyor (Bourriaud, 2014:22).

\section{Jake ve Dinos Chapman}

Jake ve Dino Champan kardeşler 1962 yılında Londra'da doğmuştur. 1988 yılında birlikte çalışmaya karar veren sanatçılar, 1991 yılında ilk kez birlikte eser üretmişlerdir. Yeniden üretim, sanat tarihi, felsefe, yapay zeka, sibernetik gibi birçok kavramı geniş bir entelektüel alt yapıyla eserlerine aktarmaktadırlar. 1995 yılına kadar birçok yerde eserleri üretilse de, 1995 yılında Genç İngiliz Sanatçılar olarak Venedik Bienali'nde eserlerinin görülmesi dikkatleri çekmiştir. Dünyanın 
birçok yerinde sergi açmış olan ikili, 2018 yılında da Türkiye'de Arter organizasyonu ile bir sergi açmışlardır.

İkili olarak sanat üretimi durumu, sanatın özellikle 1960 'larla yaşadığı dönüşümünün izlerini barındırmaktadır. Bu sadece fikir bazlı değil fiziksel bir çekilmedir aynı zamanda. Böylece, eser ve izleyici arasındaki temas ve eserin taşıdığı bilginin önemini vurgulamaktadır. Bu duruma ilk olarak Marcel Duchamp'ın fikir bazlı üretiminde görmek mümkündür; fakat bunun yanında, fikrin sanat yapıtının kurucu öğesi olması ile birlikte postmodern bir üretim biçimi olarak sanatçıların ortak üretimlere imza attığını görmek mümkündür. Chapmanların da bu referansla yola çıktığı açıktır.

Sanat yapıtının bir başka yapıta kaynaklık etmesi şüphesiz sanatçılar arası bir diyaloğun başlangıcı olduğu kadar zamansal bir kaymayı da (sıçramayı) akla getirmektedir. Chapmanların Francisco Goya'ya dönüşü veya kurmaya çalıştıkları diyalog da bu yönde bir zamansal sıçramanın oluşmasına olanak sağlamaktadır. Chapmanlar ve Goya arasındaki zamansal mesafe ve çağlar arasındaki değişkenlik, çağları iç içe geçirdiği kadar, çağdaşın ne olduğunu da sorgulamaktadır. Bu noktada çağın ve çağdaşlığın ne olduğu da önemlidir. Zamansal olarak bir yapıtın başka bir zamanda tekrar görünürlük kazanması çağdaşlık kavramını gündeme getirecektir. Giorgio Agamben'in Çağdaş nedir? sorusu etrafında biçimlendirdiği kuramsal felsefe semineri konuyu açmamıza yardımcı olacaktır. “...yukarıdaki sorulara cevap ararken araştırmamıza yönlendirecek ilk ve geçici işaret Nietzsche'den geliyor. College de France'daki derslerinden birinde Roland Barthes bunu şu şekilde özetliyor: “Çağdaş olan erken (Vakitsiz) olandır” (Agamben, 2017:17).

Çağdaş olan zamanın sürekliliği içinde kalıcı olandır da. Çağdaş sadece şimdinin karanlığını algılayan, hedefine asla varamayan bir ışığı yakalayan kişi olmakla kalmaz; o aynı zamanda, zamanı bölerek ve araya sokarak, onu dönüştürme ve başka zamanlarla ilişkiye geçirme becerisine sahip kişidir. Tarihi hiç bilinmeyen şekliyle okuyabilir; kafasına öyle estiği için değil, karşılık vermeden edemediği bir zaruret uyarınca tarihi alıntılamak için (Agamben, 2017:27).

Belli ki Chapman kardeşler tarihsel olarak Goya'ya yaptıkları müdahaleyle tarihsel olarak yeniden bir okuma gerçekleştirmektedir. Böylesi müdahale aynı zamanda aydınlanmacı ideolojinin eksik bıraktığı karanlık yanı tarihsel olarak ona eklemlemektir. 
Ayrım yapmak, onu aynılaştırmaktan ziyade farklılaştırmaktadır imgeyi zaman ve uzam bağlamında tersine çevirmektedirler. Adorno müze-mozole (museum-mousoleum) kelimeleri arasında yalnızca bir fonetik benzerlik olmadığını, kavram olarak da benzediklerini söylerken, müzeye giren eserin ölüm ile yüzleştiğini bir mezarlığa girdiğini ifade etmektedir. Chapmanlar ise müze içinde korunan o imgeyi (belki de Adorno'nun değindiği ölü imgeyi) bağlamından koparıp, ölümden hayata döndürdüğü düşünülebilir. Elbet bu bir paradoks yaratır çünkü yeni imge yani sanat nesnesi de müzeye ya da bir koleksiyona girecektir. Görsel yabancılaşma yaratan sanat nesnesi, bir öncekini yapıbozum ve yapısöküme uğratır. Öznel olan yurtsuzlaşır. Fakat bunun aksine Chapmanlar, Adorno'nun sunduğu ölüm metaforunun ötesine, aslında Goya'nın durduğu yerin ölümlüler alanı değil, Goya'nın yanlış yere konumlandığını, modernizmde değil de çağdaş bir alanda durduğunu öne sürmektedirler aynı zamanda. Hackworth'un işaret etiği gibi Chapmanlar “...resimlerin şiddetiyle (Goya’nın) gravürleri yaparken başvurduğu kompozisyon yaklaşımı arasında sıkı bir süreklilik söz konusudur. Başka bir değişle, resimsel olarak şiddeti ve dehşetti yoğunlaştıracak şekilde, natüralizm pahasına tasarlanmıştır" (Hackworth, 2018:14). Savaşın Felaketleri dizisi ve Chapmanların bu diziyi günümüze getirmesi ve bu günde yaptıkları müdahale ile yeniden üretmeleri Goya'nın üretim mantığı ile de örtüşmektedir. Chapmanların Goya'nın resimlerinden, özellikle de "Büyük Marifet! Ölülere Karşı!"dan hareketle yaptıkları oyuncu yinelemeler ve yeniden üretimler, kaynak imgeleri algılanan simgesel anlamlarından boşaltma sürecini hızlandırır; "sıfır kültürel değere sahip" bir sanat üretimini amaçlayan bir yöntemdir bu (Hackworth, 2018:14).

Bir diğer bakış açısıyla, çağının ötesinde duran Goya, aslında tam da günümüz dünyasına bir ayna tutar niteliktedir. Görünmeyen “Büyük Marifet! Ölülere Karş!!” günümüzdeki saklanmaya çalışılan dehşetin sarkastik bir göndermesidir. Zeka ve entelektüel yapı ile bezenmiş çağ sıçraması, izleyiciye çağdışılık ya da çağın içinde olabilmenin derinliğine çekmektedir. Goya, yıllar sonra böyle bir geri dönüşle modernizmin kasvetli sınırlamalarından intikam alır Chapmanlar aracılığıyla. Bu yüzden de günümüz insanına sorulması gereken soruyu sorar, Çağdaşlık nedir? Yaşanılan çağın dramına tanıklık ederken, bunu tamamen içselleştirmektedir mi günümüz insanı? Agamben'in sözleriyle: 
Çağdaşlık, birisinin, kendisine bağlı olduğu ve aynı zamanda ona olan mesafesini koruduğu kendi zamanıyla kurduğu tekil bir ilişkidir. Daha açık söylemek gerekirse bu ayrışma ve anakronizm aracılığıyla bağlı olunan zamanla kurulan bir ilişkidir. Çağıyla iyi bir biçimde uyuşanlar, ona her bakımdan tamamen bağlı olanlar, tam da onu nasıl göreceklerini bilemediklerinden, ona bakmayı beceremediklerinden dolayı çağdaş değildir (Agamben, 2017:27).

Tüm bu bilgiler ışığında Goya ve Chapmanlar arasındaki bağa eserler aracılığı ile bakmak gerekirse, karşımıza çıkan şey çağlar arasındaki sıçramanın ötesindedir. Chapmanlar Goya'nın baskı resim serisi olan Savaşın Felaketleri'ne odaklanarak, yeniden üretim bağlamında bir seri eser üretmişlerdir. Peki, Goya'nın serisi tam olarak neyi hedefliyor ve izleyiciye ne diyordu? Francisco Goya'nın yağlı boya resimleri kadar, üç yüze yakın farklı gruplara ayrılmış baskı resimleri bulunmaktadır. Bunlar, Savaşın Felaketleri, Kaprisler, Boğa Güreşi, Atasözleri ve Bourdeaux Boğaları olarak adlandırıımış serilerdir.

Tek tek bütün gravürleri ve edisyonları sayarsak, Chapmanların Goya ile bağlantılı binin üzerinde iş ürettiklerini söyleyebiliriz. Bunların çoğu 82 gravürden oluşan ve yaygın olarak "Savaşın Felaketleri" diye anılan, 1808 ile 1814 arasında iber Yarımadası'nda yaşanmış, işgalci Fransız kuvvetlerinin ispanyol, Britanyalı ve Portekizli kuvvetlerle çarpışı̆ı̆ı Yarımada Savaşı'ndan şiddet sahneleri betimleyen seriye odaklanır (Hackworth, 2018:12).

Goya'nın 1809-1814 yılları arasında ürettiği 82 adet baskıdan oluşan Savaşın Felaketleri adlı serisinde ise, döneminin ve öncesi sanatçıların savaşı aktarışının dışında, alışılmış savaş algısından farklı görüntüler sergilemektedir. Diğer bir deyişle, savaşı iktidar referansıyla değil de, savaşın dramatik yönlerini, şiddetini ve kurbanların çektiği dramı gözler önüne sermektedir. Bununla birlikte Goya, 1808' de başlayan İspanyol İç Savaşı'nı birer belge gibi eserleriyle çağımıza aktarmaktadır. Susan Sontag Başkalarının Acısına Bakmak adlı kitabında Goya'nın Savaşın Felaketleri serisi için şunları demektedir:

Savaşın Felaketleri'nde iğrenç zalimliklerin sergilenmesiyle hedeflenen, besbelli ki o görüntülere bakanları uyandırmak, sarsarak şok etmek ve derinden yaralamaktır. Goya'nın sanatı, Dostoyevski'ninki gibi, ahlaki duygular ve kederin tarihinde (eserlerinin derin, özgün, ilgi ve merak çeken niteliğiyle) bir dönüm noktasında duruyor görünmektedir. Goya'yla birlikte sanata, acıya duyarlılık açısından yeni bir standart gelmiştir. Savaşın zalimliklerinin dökümü, izleyicinin duyarlılı̆ına bir saldırı şeklinde tasarlanmıştır. Her resmin altındaki yazılı açıklayıı ifadeler, resmin bıraktığı izlenime kışkırtıcı bir boyut katarlar. Resimler, her görüntü gibi "bakma” ya çıkarılmış bir davetiye iken, resimlerin altındaki yazılar çoğunlukla sadece bakmanın güçlüğü ve yetersizliği üzerinde dururlar. Bir ses muhtemelen sanatçının sesi izleyiciyi kızdırıp köşeye sıkıştırır: 
Bu resme bakmaya dayanabilir misiniz? Bir resmin başlığında açıkça şu bildirilir: "Buna bakılamaz" (No se peuda mirar). Başka bir resim yazısı şunu söyler: "Bu kötüdür" (Esto es malo). Başka bir resim yazısı anında kestirip atar: "Bu daha kötüdür!" (Esto es lo peor!). Bir başkası şöyle haykıır: "Barbarlar!" (Barbaros!). Bir başkası feryat eder: "Bu ne delilik!" (Que locıra!). Bir diğeri şöyledir: "Artık bu çok fazla!" (Fuerte cosa es!). Bir başkası da der ki: “Niçin?" (Por que?) (Sontag, 2004:44-45).

Savaş ve dehşet, çağlar öncesinde kalan bir şey değildir. Günümüz insanı (belli şanslı bir grup) da, doğrudan kurban olmasa da televizyon ve internet aracılığı ile savaşve şiddetin acımasız tarafına tanıklık etmektedir. Diğer bir değişle, günümüz insanı en korkunç görüntüleri, yani Goya'nın dediği gibi "buna bakılamaz" şiddetindeki gibi insanlık dışı görüntüleri görmek zorunda kalmaktadır. Bu karamsarlık ve içinde kötümserlik barındıran görüntüler, tıpkı geçmişteki gibi günümüzü de tüm olumsuz duygularıyla birlikte içine çekmektedir. İşte bu nokta, Chapmanların Goya'dan etkilenmesinin tesadüf olmadığını düşündürmektedir. İkilinin Goya ile iletişimlerini Nick Hackworth şu şekilde açıklamaktadır: Chapmanların kötümserlikleri en fazla, Goya'nın eserleri ile fikirleriyle uzun süren ve kapsamlı ilişkilerinde görünürlük kazanır.

Çağlar arasındaki şiddet örüntüsü benzerlik gösterse de, Chapmanların sadece bu örüntü ile bir bağ kurduklarını ve yeniden üretime geçtiklerini söylemek güçtür. Çünkü sadece şiddetin görünürlüğünü açığa çıkarmanın dışında çağlar arasında bir hesaplaşmanın defterini de açmaktadırlar. Şiddetin ve kötücüllüğün değişmeyen yüzünün hesaplaşmasıdır bu. Başka bir deyişle, bağlamından koparılan Goya'nın dehşet verici görüntüleri ile çok da yeni bir görüntüye ihtiyaç duymadan çağımıza ayna tutmaktadırlar. Goya'nın eserlerindeki ağaca ya da çarmıha asılmış ve parçalara ayrılmış insan bedenleri, ikilinin çalışmalarında, Nazi imgesiyle birleşmektedir. Maketler ve yığıntılarla oluşturdukları kompozisyonları kaotik bir ortam yaratmaktadır. Her yerden bir imge, simge ya da zihni kışkırtacak başka bir görüntü çıkmaktadır. Oluşan kompozisyonlar dehşetin taklidi gibidir. Şiddet yabancılaştırılarak uzak bir kavrammış gibi görülmeye başlanabilir ancak şiddet hiç de uzakta değildir. Bu bağlamda, yakın tarihin en utanç verici katliamlarını yapan Naziler, şeytani kötücüllüğün dünyadaki imgesidir adeta. Sanatçılar kötücüllüğe odaklanırken, insanın şeytansı bir noktaya nasıl geldiğinden ziyade, o kötücüllükle tarihe nasıl bir iz bıraktıklarını izleyiciye sunmaktadır ve o dehşeti hatırlatmaktadır. Yine çarmıha gerilme imgesini McDonald's'ın simgeleşen palyaçosu ile örtüştürürler. Şiddet ve kapitalizm ilişkisini, semboller ve metaforlar aracılığı ile sunmaktadırlar. Çalışmanın adında da anlaşılacağı 
üzere "Öbür Dünya” olarak kastedilen ölümün olduğu ve belirsizlik dünyasıdır ya da kutsal dinlerde hesaplaşma günü olarak belirtilen yerdir. Ve o hayalin içinde, Nazi, Hitler, McDonald's ve şeytani kötücüllük bir aradadır. "Bu bir tesadüf müdür?" sorusu izleyicinin düşünme alanına bırakılmaktadır. Diğer taraftan sanatçılar savaş karşıtı fanatizmi gibi alanda bir taraf tutmazlar; yalnızca eserle izleyiciyi baş başa bırakmaktadırlar ve çağlar arasındaki yaşanan bu dehşet ve benzerlik üzerine düşünme mesafesini bırakmaktadırlar.

Savaşın Felaketleri serisi içinde, ağaca bedeni parçalanarak asılan figürün bulunduğu “Büyük Marifet! Ölülere Karşı!” adlı 39. gravüre sanatçıların yoğunlukla odaklandıkları görülmektedir. Aynı çalışmayı hem maketlerle ve heykelle, hem de gravürlerin üzerine boya veya resimlerle doğrudan müdahale ederek yeniden üretime geçmişlerdir. Bu çalışmalar:

Etkileyici bir yetkinlikle, çarmı germenin ve Hristiyanlıktaki Teslis'in ikonografisiyle dalga geçer gibidir. Chapmanların dediği gibi: "Büyük Marifet! Ölülere Karşı!" özellikle heretik bir resimdir, çünkü bu bedenin herhangi bir şekilde kurtarılabileceği fikrini bütünüyle reddeder." Onun yerine resim "yerçekimi nosyonunu, entropi nosyonunu ve çürüme nosyonunu..." betimler ve bu temeldeki maddeselliğin "bir türh uhrevi kurtuluş fikriyle içkin biçimde yan yana gelmesi büyük bir makas değiştirmedir ve az buz şiddet değildir dünya üzerinde (Hackworth, 2018:12).

Bununla birlikte, daha önce de değinildiği gibi Chapmanlar Modern sanatın ilerleyici, sınıflandırıcı yapısını eleştirirken, Aydınlanma çağının reddedilen, görmezden gelinen ya da inkar edilen kötümserliğini de vurgulamaktadır. Chapmaların Nick Hackworth ile yaptıkları röportajda, Goya'nın serisine eğilmelerindeki nedeni ve önemi üzerine sorulan soruya şu yanıtı verdikleri görülmektedir:

Goya'nın "Savaşın Felaketleri" serisi, hurafenin tam da modern Aydınlanma'nın elindeki sefil kaderi tasvir eder. Zavallı insanlığın, Hristiyanlığın metruk yıkıntılarında ayak sürmesini resmeder. "Tanrının ölümü”nün adli izi o mahut "Büyük Marifet! Ölülere Karş!!" gravüründe aşikardır. Bu gravürde, üç cesetten oluşan kutsal olmayan bir teslis ağaca bağlanmış; kefaretten yoksun, güneşin alnında asılı bırakılmışık, heretik bir Newtoncu yerçekimine tabi kılınmıştır -selametin tek yolu çürüyüp toprağa karışmaktır... "Yaraya Tuz", bir şeyi müşfik bir ilgiyle aşındırmanın iyi mi yoksa kötü mü olacağını anlamak için yapılan bir deneydi. Yıkıcı bir edimin, zaten büyük saygı duyulan bir şeye artı değer katıp katmayacağını görmek istedik (Chapman, 2017:26)

Sanatçıların Yaraya Tuz serisinde ilk olarak teslis ağacına asılmış parçalanmış bedenlerin gerçeğe yakın maketler yaptığı görülmektedir (Görsel 1). Onlarca çeşitlemesini yaptıkları teslis ağacına asılmış figürlerin bulunduğu eserler, kendilerinin de röportajlarında değindiği gibi bir tür 
deneydir ve eserlerin hepsine toptan bakıldığında deneyin adım adım ilerlediği görülmektedir. Böylece her yeniden üretim ayrı bir çağrışım ve anlam barındırır. Cüneyt Çakırlar (2017:66)'ın yorumuyla: “Goya'nın savaş sahneleri, Chapmanların kariyerlerinin seyri boyunca çeşitli taklit, temellük ve ihlal stratejileri üzerinden sürekli ilişkilendirdikleri kilit bir izlek işlevi görür". Elbette Goya'ya dönüş en başta da belirtildiği gibi rastlantısal değildir. Çağlar öncesine ait şiddet görüntüleri günümüzde de yaşanmaktadır. Yakın tarihimizden başlayarak Nazilerin korkunç katliamları, Afrika kıtasında yaşanan soykırım görüntüleri ve günümüzde IŞID terör örgütünün internete sızdırılan kurbanların infaz görüntüleri, Goya'nın gösterdiği şiddetten çok farklı değildir. İkilinin maket mankenden yaptıkları Goya'nın “Büyük Marifet! Ölülere Karş!!” yeniden üretiminde, parçalanmış bedenin teşhiri ve şiddetini bu bağlamda doğrudan gösterir. Fakat bu manken dışında, farklı maketler de bulunmaktadır. Aynı görüntünün, yanmış ağaç çeşitlemesi, figürlerin iskelete dönüşmüş çeşitlemesi gibi birçok varyasyonu bulunmaktadır. Bununla birlikte Şanssızlığın Tekeri (Görsel 1.) adlı çalışma için Cüneyt Çakırlar (2017:68)'ın sözleri dikkat çekicidir:

Chapmanların "Grande hazana" yı heykel mecrasında yeniden canlandırırken Goya'yı mülk edinme mantıkları Goya'nın ölüm temsiliyle çelişmez, aksine o temsilin libidinal ekonomisini yüceltir. Chapman ikilisinin çalışmaları, Jameson'ın "postmodern pastiş" dediği şeyler, yani boş bir metinsellik addedilen kopya ve taklit kavramlarıyla hiç de uyuşmaz. Chapmanların boşluğu ve kofluğu gerçekleştirme tarzları “öznenin ölümü”nü tekrar etmeye değil, ölümü özne olarak politikleştirmeye hizmet eder. Bu estetik bir ataleti vücuda getirmeyi ve "ölü bir heykel, içerik olarak ölü ve dahası madden ölü- ya da atıl- bir heykel ortaya çıkarmayı "hedefleyen performatif bir gündem içerir. 
SDÜ ART-E

Güzel Sanatlar Fakültesi Sanat Dergisi

Haziran'19 Cilt:12 Sayı:23 ISSN 1308-2698

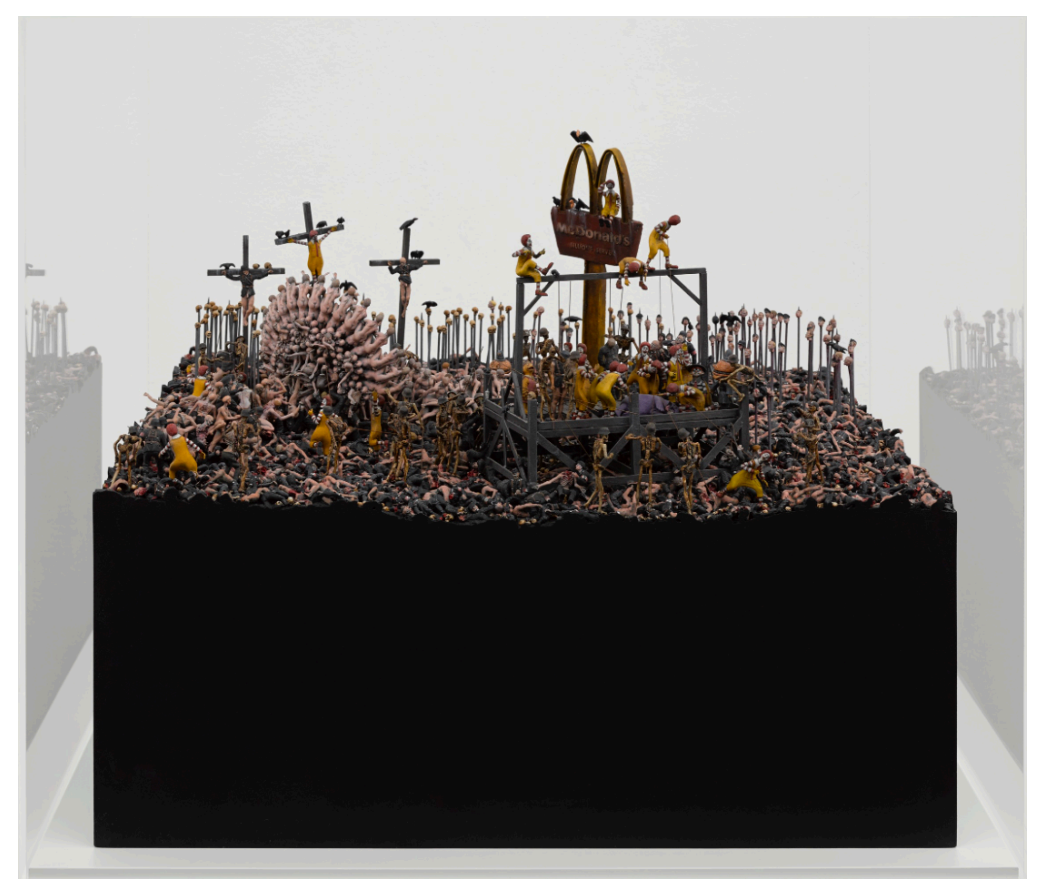

Görsel 1. Jake ve Dinos Chapman, Şanssızlı̆̆ın Tekeri, 2014, Fiberglas ve Karışık Teknik, Özel Koleksiyon.

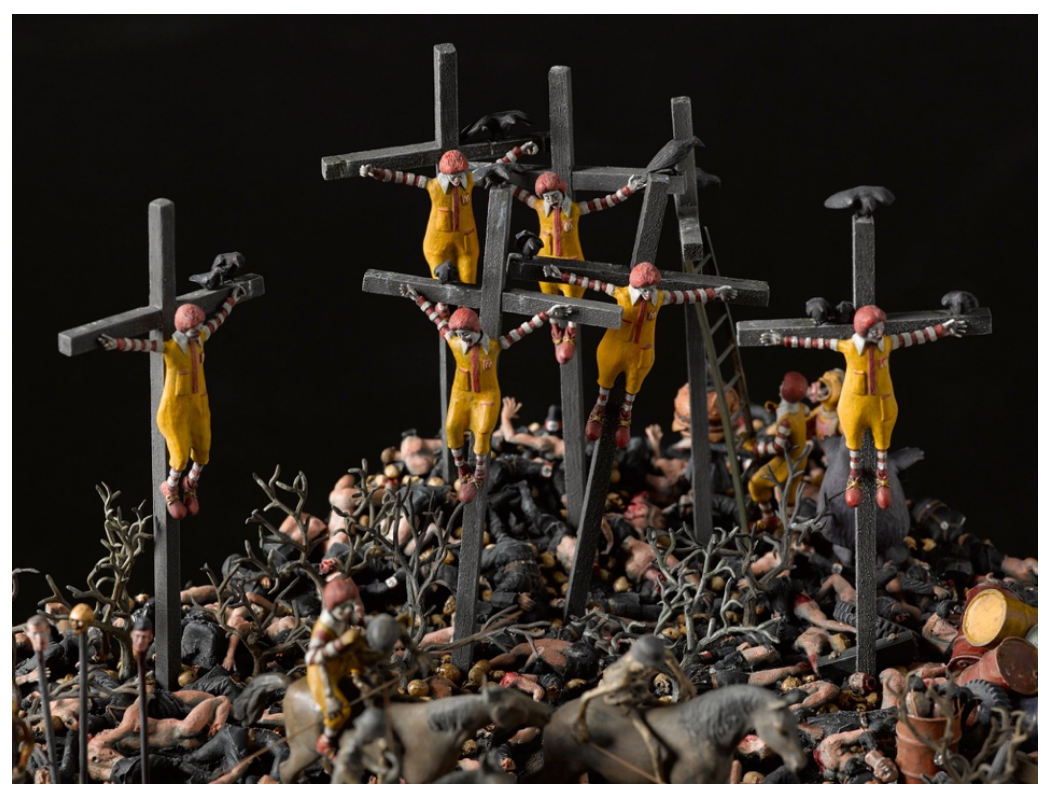

Görsel 1 a. Detay

İkilinin Savaşın Felaketleri serisindeki birçok gravüre yaptığı müdahaleler de dikkat çekicidir. Gravürleri tekrar kopyalamaları yeniden üretim bağlamında önem barındırdığı kadar, alma, çalmanın ötesinde, yani daha önce de değinildiği gibi "postmodern pastiş"in ilerisinde 
durmaktadır. Chapmanların 39 numaralı gravüre yaptıkları müdahale çeşitlemelerinde, maske, palyaço, gülünç, kahkaha gibi kavramlarla yeniden üretime geçtikleri görülmektedir (Görsel 2). Bununla birlikte Goya'nın ölü bedeninin sergilenmesi, teşhir edilmesindeki etkiyi mizahla ele aldıkları görülmektedir. Fakat bu ilk anda göze çarpan mizah, altında günümüzde yaşanan şiddet kurbanlarının, düşman ve öteki tartışmalarını da tartışmaya açmaktadır.

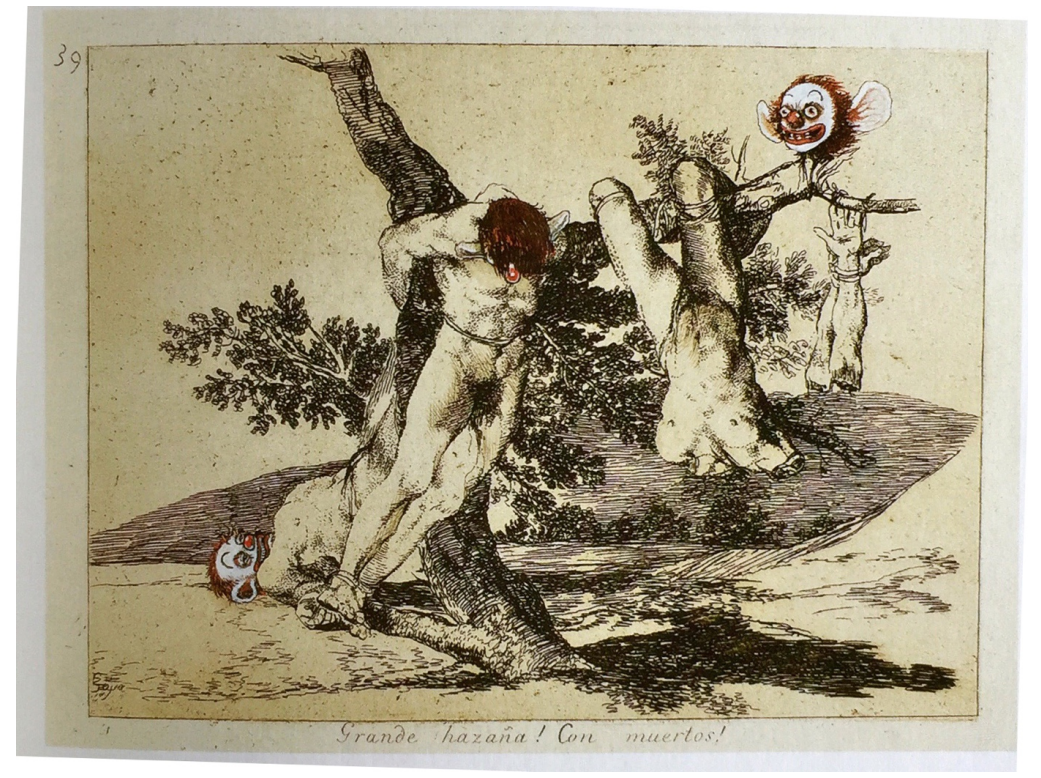

Görsel 2. Jake ve Dinos Chapman, Büyük Marifet! Ölülere Karşı!, 2001, Baskı Üzerine Müdahale, $15.6 \times 20.8 \mathrm{~cm}$, Özel Koleksiyon.

Günümüzde, gündelik yaşamda maruz kalınan şiddet görüntülerinin ve ekranlara yansıyan görüntülerin politik bir mesaj içerdiği düşünülebilir. Görüntüler içerik olarak doğrudan düşmanı göstermeyen ama düşmanın konumunu ve yapabileceği şiddetin örneği olması bakımından önemlidir. Diğer bir deyişle bu görüntüler, düşmanı kurbanlar üzerinden tanımlayan/tanımlatan türden görüntülerdir. Tam da bu noktada Çakırlar, sanatçılar hakkında yazdığı metinde, sanatçıların izleyiciyi günümüz uluslararası siyasetin yarattığı politik argümanları, günümüz insanının savaş algısını sorgulamaya yönelttiğine değinir ve "Büyük Marifet! Ölülere Karşı”ya (Görsel 3) yönelik şu çıkarımlarda bulunur:

Jake ve Dinos Chapman "postmodern dışkılamanın abesliği"ni taklit ederken, bunu "düşman ilan edilenle doğrudan karşılaşmanın eksikliği"nin bir semptomu haline getirirler: Goya'nın bu yeniden yorumlanışındaki performatif bayağılık, günümüzün savaş imgesinin bedenlerden arındırılmışlığının nasıl da özneyi "düşman öteki"ye duyduğu arzuda kendisini tanımaktan aciz bıraktığını" ve dahası bu savaş imgesinin nasıl da 
“öznenin parçalanmış beden (imago) nostaljisini postmoden bir fanteziye dönüştürdüğünü" gözler önüne serer (Çakırlar, 2017:70).

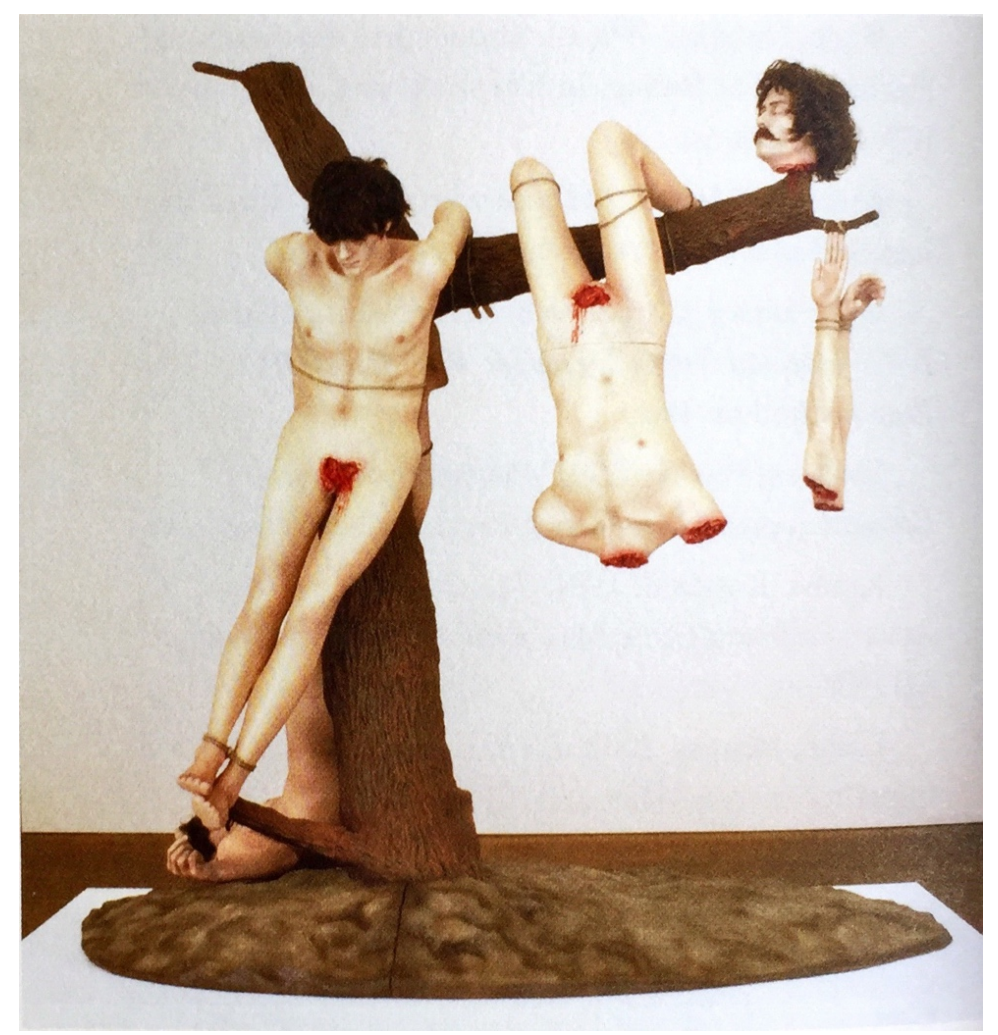

Görsel 3. Jake ve Dinos Chapman, Büyük Marifet! Ölülere Karşı!, 1994, Fiberglas ve Karışık Teknik, Özel Koleksiyon.

\section{Sonuç}

1960 sonrası kavrama dayalı sanat hareketleri içerisinde yeniden üretime dair birçok örnek bulunduğu bilinmektedir. Sanatın yanında, birçok tasarım alanı da yeniden üretimden etkilenmiştir. Bu açıdan bakıldığında da, yeniden üretim ya da temellük kavramlarının postmodernizm ile yakın bir ilişkisi olduğunu söylemek mümkündür. Postmodernizm düşünce ve anlatı anlamındaki katkıları ve teknolojinin devrimsel nitelikteki dönüşümü, görsel sanatlarda eklektik ya da var olanı bozup yeniden inşa etme üzerinden bir eğilime yönelmektedir. Chapmanlar da yeniden üretim bağlamında eserleriyle dikkat çekmektedir. Öncelikli olarak ikili olarak tek eser üzerine odaklanmaları önemlidir. İkili olarak sanat üretimi durumu, sanatın özellikle 1960’larla yaşadığı dönüşümünün izlerini barındırmaktadır. Bu sadece fikir bazlı değil 
fiziksel bir çekilmedir aynı zamanda. Böylece, eser ve izleyici arasındaki temas ve eserin taşıdığı bilginin önemini vurgulamaktadır.

Chapmanların Francisco Goya'ya dönüşü veya kurmaya çalıştıkları diyalog bir zamansal sıçramanın oluşmasına olanak sağlamaktadır. Chapmanlar ve Goya arasındaki zamansal mesafe ve çağlar arasındaki değişkenlik, çağları iç içe geçirdiği kadar, çağdaşın ne olduğunu da sorgulamaktadır. Sanatçılar bu çağlar arası değişiklik kadar, Aydınlanma felsefesini sorgulayan çalışmalar üretmektedirler. Goya'nın 82 parçadan oluşan Savaşı Felaketleri serisi içinde, ağaca bedeni parçalanarak asılan figürün bulunduğu "Büyük Marifet! Ölülere Karşı!” adlı 39. gravüre sanatçıların yoğunlukla odaklandıkları görülmektedir. Aynı çalışmayı hem maketlerle ve heykelle, hem de gravürlerin üzerine boya veya resimlerle doğrudan müdahale ederek yeniden üretime geçmişlerdir. Savaşın Felaketleri serisinde, hurafe ve modern Aydınlanma'nın aciz durumunu ortaya koymayı amaçladıkları görülmektedir. Ve kendilerinin deyimiyle, bu üretimler bu aşındırmanın iyi veya kötü sonucuna dair bir tür deneydir. Bu deneyler en korkunç görüntüleri "buna bakılamaz" şiddetini günümüze taşımaktadırlar. Bu karamsarlık ve içinde kötümserlik barındıran görüntüler, tıpkı geçmişteki gibi günümüzü de tüm olumsuz duygularıyla birlikte içine çekmektedir. İşte bu nokta, Chapmanların Goya'dan etkilenmesinin tesadüf olmadığını düşündürmektedir. Çağlar arasındaki şiddet örüntüsü benzerlik gösterse de, Chapmanların sadece bu örüntü ile bir bağ kurduklarını ve yeniden üretime geçtiklerini söylemek güçtür. Çünkü sadece şiddetin görünürlüğünü açığa çıkarmanın dışında çağlar arasında bir hesaplaşmanın defterini de açmaktadırlar. Şiddetin ve kötücüllüğün değişmeyen yüzünün hesaplaşmasıdır bu. Başka bir deyişle, bağlamından koparılan Goya'nın dehşet verici görüntüleri ile çok da yeni bir görüntüye ihtiyaç duymadan çağımıza ayna tutmaktadırlar.

\section{Kaynakça}

Adorno, T. (2003). "Kültür Endüstrisini Yeniden Düşünürken", Cogito, çev. Bülent O. Doğan, Sayı 36, s.76-83 İstanbul: Yapı Kredi Yayınları.

Agamben, G.(2017). Çıplaklıklar, çev. Suna Kılıç, İstanbul: Alef Yayınevi.

Bourriaud, N. (2004). Postprodüksiyon, çev. Nermin Saybaşılı, İstanbul: Bağlam Yayıncılık. 
Chapman, J. (2017). "Yaraya Tuz... ya da Talihlilerin Talihsizlerden Faydalanması", Jake ve Dinos Chapman-Anlamsızlık Aleminde, ed. Süreyya Evren, İstanbul: Arter Yayınları, s.34-45.

Çakırlar, C. (2017). “Estetik Atalet, Dokunaksı Ölüm: Jake ve Dinos Chapman'ın Alabildiğince Banal Sanatı Üzerine", Jake ve Dinos Chapman-Anlamsızlık Aleminde”, ed. Süreyya Evren, İstanbul: Arter Yayınları, s.60-75.

Hackworth, N. (2017). "Jake ve Dinos Chapman'ın Kötümserliği", Jake ve Dinos ChapmanAnlamsızlık Aleminde”, ed. Süreyya Evren, İstanbul: Arter Yayınları, s.12-19.

Ranciere, J. (2006). Estetik Bilinçdışı, çev. Kenan Sarıalioğlu, İstanbul: Ara-lık Yayınları.

Sontag, S. (2004.) Başkalarının Acısına Bakmak, çev. Osman Akınay, İstanbul: Agora Kitaplığı.

\section{Internet Kaynakları}

Artun A. (2013) "Sahte Sanat, http://www.e-skop.com/skopbulten/sahte-sanat/1162, Erişim tarihi: 10.02.2019.

\section{Görsel Kaynakça}

Görsel 1. Jake ve Dinos Chapman, "Şanssızlığın Tekeri", 2014.

https://www.wired. com/2014/01/chapman-hellscapes/, Erişim tarihi: 02.01.2019.

Görsel 1a. Jake ve Dinos Chapman, "Şanssızlığın Tekeri", (Detay), 2014.

http://jakeanddinoschapman.com/works/wheel-of-misfortune/ Erişim tarihi: 02.01.2019.

Görsel 2. Jake ve Dinos Chapman, Büyük Marifet! Ölülere Karşı!, Baskı, 2001. Çakırlar, C. (2017). "Estetik Atalet, Dokunaksız Ölüm: Jake ve Dinos Chapman'ın Alabildiğince Banal Sanatı Üzerine", Jake ve Dinos Chapman-Anlamsızlık Aleminde", ed. Süreyya Evren, İstanbul: Arter Yayınları, s.60-75.

Görsel 3. Jake ve Dinos Chapman," Büyük Marifet! Ölülere Karş!!", 2001.

http://jakeanddino schapman.com/works/insult-to-injury/1811/, Erişim tarihi: 02.01.2019. 